\title{
PERAN PENGELOLA AGROWISATA DALAM MENGENTASKAN KEMISKINAN MASYARAKAT PEDESAAN \\ (Studi kasus di Desa Cihideung Kecamatan Parongpong Kabupaten Bandung Barat)
}

\author{
Lia Siti Maulida \\ Prodi Pendidikan Masyarakat IKIP Siliwangi Bandung \\ liamaulida1977@gmail.com
}

\begin{abstract}
ABSTRAK
Agrowisata merupakan bagian objek wisata yang memanfaatkan usaha pertanian sebagai objek wisata. Sampai saat ini berbagai objek wisata yang potensial relatif belum banyak menarik pengunjung, antara lain karena terbatasnya sarana dan prasarana yang tersedia dan kurangnya promosi dan pemasaran kepada masyarakat luas baik di dalam maupun di luar negeri. Untuk itu perlu ditempuh suatu koordinasi promosi antara pengelola dengan berbagai pihak yang berkecimpung dalam bidang promosi dan pemasaran objek-objek agrowisata, baik instansi pemerintah maupun pihak swasta. Agrowisata ini adalah merupakan salah satu upaya masyarakat dalam meningkatkan perekonomiannya sehingga dapat mengentaskan kemiskinan masyarakat pedesaan pada umumnya. Penelitian ini bertujuan untuk mengkaji tentang peran pengelola agrowisata dalam mengentaskan kemiskinan masyarakat pedesaan. Jenis penelitian ini adalah deskriptif Analitik dengan menggunakan teknik penelitian yaitu observasi, wawancara dan menggunakan populasi dan sampel. Subjek penelitian adalah pengelola agrowisata yaitu Gabungan Kelompok Tani yang berada di Desa Cihideung Kecamatan Parongpong Kabupaten Bandung Barat. Hasil penelitian menunjukan bahwa peran pengelola agrowisata sangatlah penting mulai dari perencanaan maupun pengelolaan hingga pemasaran produk dari agrowisata ini untuk meningkatkan kesejahteraan masyarakat pedesaan dalam upaya pengentasan kemiskinan di Desa Cihideung
\end{abstract}

Kata Kunci : agrowisata, pengentasan kemiskinan, Masyarakat Pedesaan

\section{PENDAHULUAN}

Kemiskinan adalah merupakan masalah yang banyak dihadapi oleh banyak negara terutama negara-negara yang sedang berkembang dan merupakan masalah yang sangat kompleks, Kemiskinan yang terjadi di tengah masyarakat disebabkan oleh berbagai faktor dan saling berkaitan erat antara faktor yang satu dengan faktor yang lainnya sehingga memperburuk keadaan tersebut. Selain itu kemiskinan hanya akan membuat keterpurukan dan terisolasi sosial. Kondisi kemiskinan akan mempengaruhi kualitas hidup secara umum dan kesejahteraan hidup masyarakat.

Indonesia terletak di negara yang beriklim tropis, memiliki tanah yang subur sehingga membuat beberapa wilayah di Indonesia potensial untuk dikembangkan menjadi kawasan agrowisata. Agrowisata merupakan bagian dari objek wisata yang memanfaatkan usaha pertanian sebagai objek wisata yang bertujuan untuk memperluas pengetahuan, pengalaman rekreasi dan hubungan usaha di bidang pertanian. Manfaat dari agrowisata ini 
adalah mengembangkan pariwisata dengan objek dan daya tarik keindahan alam serta potensi wisata. Selain itu bermanfaat juga untuk menambah penghasilan dari penjualan jasa dari objek dan daya tarik wisata keindahan alam, sekaligus akan memperoleh hasil dari penjualan budidaya tanaman agro atau komoditas pertanian.

Sampai saat ini, berbagai obyek agrowisata yang potensial relatif belum banyak menarik pengunjung, antara lain karena terbatasnya sarana dan prasarana yang tersedia serta kurangnya promosi dan pemasaran kepada masyarakat luas baik di dalam maupun di luar negeri. Agrowisata ini adalah merupakan model agrobisnis yang bisa menjadi lahan pekerjaan baru dan mendatangkan devisa negara di masa yang akan datang. Dan itu adalah merupakan tantangan bagi berbagai pihak untuk membuat inovasi-inovasi baru dalam pengembanag agrowisata ini. Peran pengelola agrowisata dalam merencanakan dan mengelola pertaniannya sangatlah penting karena dengan adanya pengelolaan yang baik maka kesejateraan masyarakat akan tercapai dan mengurangi tingkat kemiskinan di pedesaan.

Adapun salah satu kawasan agrowisata yang terletak di daerah pedesaan yang berada di sebelah utara kota Bandung yaitu Desa Cihideung Kecamatan Parongpong Kabupaten Bandung Barat yang mayoritas penduduknya bertani khususnya bertani bunga dengan menjadikan daerah pedesaannya menjadi daerah wisata bunga atau agrowisata yaitu dengan mejadikan lahan-lahan pekarangan rumah warga masyarakatnya menjadi lahan pertanian bunga baik bunga potong maupun bunga hias yang bisa dijual dan menghasilkan pendapatan bagi penduduknya. Jalur Desa Cihideung letak daerahnya sangat strategis dengan tempat wisata alam, yaitu dekat dengan wisata Tangkuban Perahu, dimana daerah ini sering dilewati pengunjung domestik untuk berwisata alam. Hampir 85\% penduduknya membangun green house ( rumah bunga) di area rumah pekarangannya, yang diantaranya tanaman hias, yang berjajar dan tertata rapi di setiap sudut pekarangan depan rumah penduduk Desa Cihideung. Para pengunjung atau wisatawan yang kebetulan melewati Desa Cihideung, pada umumnya sangat tertarik untuk membeli dan aneka bunga hias dan tanaman hias tersebut.

Kemajuan Desa Cihideung ini tidak lepas dari peran dari gabungan kelompok tani yang merupakan unsur pengelola agrowisata di Desa Cihideung ini dengan model manajemen agrobisnis yang diterapkan mulai dari perencanaan,pengelola dan pemasaran hasil dengan sasaran dan tujuan yang baik, dan salah satu programnya yaitu Program Sekolah Lapangan (SKL) dan penyuluhan-penyuluhan pertanian kepada masyarakat di Desa Cihideung ini sehingga agrowisata ini dapat menjadi alternatif upaya dalam pengentasan kemiskinan di daerah Cihideung dan menjadikan masyarakatnya lebih sejahtera serta menjadikan Desa Cihideung sebagai salah satu tempat pariwisata bunga atau agrowisata yang sangat terkenal di Kabupaten Bandung Barat Provinsi Jawa Barat

\section{LANDASAN TEORI}

\section{A. Agrowisata}

Agrowisata atau yang biasa di kenal dengan wisata agro adalah kegiatan wisata yang berlokasi atau berada di kawasan pertanian. Agrowisata merupakan bagian objek wisata yang memanfaatkan usaha pertanian sebagai objek wisata. Tujuannya adalah untuk 
memperluas pengetahuan, pengalaman rekreasi dan hubungan usaha di bidang pertanian. Pengembangan agrowisata yang menonjolkan budaya lokal dalam memanfaatkan lahan, pendapatan petani dapat meningkat bersamaan dengan upaya melestarikan sumber daya lahan serta memelihara budaya maupun teknologi lokal yang umumnya telah sesuai dengan kondisi lingkungan alaminya. Menurut (Yoeti, 2000, hal. 143) agrowisata merupakan salah satu alternatif potensial untuk dikembangkan di pedesaan. Kemudian batasan mengenai agrowisata dinyatakan bahwa agrowisata adalah suatu jenis pariwisata yang khusus menjadikan hasil pertanian, peternakan, perkebunan sebagai daya tarik bagi pengunjung. Pengembangan agrowisata pada prinsipnya akan menciptakan lapangan pekerjaan, karena usaha ini dapat menyerap tenaga kerja dari masyarakat pedesaan, sehingga dapat menahan atau mengurangi arus urbanisasi yang semakin meningkat saat ini. Bagaimanapun, agrowisata juga merupakan kesempatan untuk mendidik orang banyak atau masyarakat tentang pertanian. Pemain kunci didalam agrowisata ini adalah petani dan selebihnya adalah pengunjung (wisatawan) dan pemerintah atau institusi. Peran mereka bersama dengan interaksi mereka adalah penting untuk menuju sukses dalam dalam pengembangan agrowisata. Obyek agrowisata harus mencerminkan pola pertanian Indonesia baik tradisional ataupun modern guna memberikan daya tarik tersendiri bagi pengunjung. Sampai saat ini, berbagai obyek agrowisata yang potensial relatif belum banyak menarik pengunjung, antara lain karena terbatasnya sarana dan prasarana yang tersedia serta kurangnya promosi dan pemasaran kepada masyarakat luas baik di dalam maupun di luar negeri.

\section{B. Pengentasan Kemiskinan}

Kemiskinan di Indonesia dan di seluruh dunia berfokus di daerah pedesaan. Dengan sekitar 23.600.000 penduduk Indonesia hidup dibawah garis kemiskinan seperti yang didefinisikan oleh Badan Statistik Indonesia. Dan tiga perempat dari penduduk miskin Indonesia ini adalah petani di pedesaan. Kemiskinan di pedesaan Indonesia diperburuk oleh bencana alam mengingat kondisi cuaca di Indonesia tidak bisa di prediksi.

Kemiskinan menurut (Soekanto, 1995, hal. 406-407) diartikan sebagai suatu keadaan dimana seseorang tidak sanggup memelihara dirinya sendiri sesuai dengan taraf kehidupan kelompok dan juga tidak mampu memanfaatkan tenaga mental maupun fisiknya dalam kelompok tersebut.

Faktor-faktor yang menyebabkan kemiskinan di daerah pedesaan yaitu: (1) Tingkat pendidikan serta kualitas pendidikan masyarakat yang masih rendah, (2) Rendahnya asset yang dikuasai masyarakat pedesaan, (3) Pelayanan sarana dan prasarana pedesaan yang kurang memadai, (4) Terbatasnya kesempatan untuk melakukan usaha di pedesaan dan (5) Lemahnya pembangunan berbasis masyarakat dan lemahnya koordinasi didalam pembangunan pedesaan itu sendiri.

Pengentasan kemiskinan yang berkesinambungan memerlukan keterlibatan dari berbagai kalangan yaitu pemerintah pusat, pemerintah daerah, dunia usaha (sektor swasta) dan masyarakat yang memiliki tanggungjawab yang sama dalam pengentasan kemiskinan ini. Upaya pengentasan kemiskinan ini tidak cukup hanya dengan memberikan bantuan secara langsung kepada masyarakat miskin karena penyebab kemiskinan tidak hanya disebabkan oleh aspek-aspek yang bersifat materialistik tetapi juga karena kurangnya akses untuk 
memperbaiki kualitas hidup masyarakat miskin. Pengentasan kemiskinan disebut juga masalah pokok dalam pembangunan di Indonesia dan kualitas pertumbuhan ekonomi menjadi kunci pemecahannya. Permasalahan utama dalam upaya pengentasan kemiskinan di Indonesia saat ini terkait dengan adanya fakta bahwa pertumbuhan ekonomi tidak tersebar secara merata diseluruh wilayah Indonesia, ini dibuktikan dengan tingginya disparitas pendapatan antar daerah.

Indonesia telah membuat komitmen nasional untuk memberantas kemiskinan dalam rangka pelaksanaan pembangunan berkelanjutan, dimana pemerintah dan semua perangkat negara bersama dengan berbagai unsur masyarakat memikul tanggungjawab utama untuk mewujudkan pembangunan berkelanjutan. Program pengentasan kemiskinan juga tak mungkin berjalan tanpa adanya tata kelola pemerintahan yang baik, sebagai dasar bagi terlaksananya pembangunan berkelanjutan di manapun, termasuk di Indonesia.

Macam- macam pengentasan kemiskinan

Mengingat adanya dua bentuk kemiskinan yaitu Kemiskinan Absolut (Absolute Poverty) dan Kemiskinan Relatif (Relative Poverty) menurut (Awan Setya Dewanta, 1995, hal. 1119) maka pemerintah perlu menetapkan kebijaksanaan (policy, political will), strategi maupun program-program yang spesifik untuk mengentaskan kedua bentuk kemiskinan tersebut. Kemiskinan absolut harus dilihat sebagai prioritas, darurat (emergency) sifatnya dan memerlukan penanganan jangka pendek sampai menengah, karena biasanya permasalahan yang dihadapi tidak dapat menunggu terlalu lama dan membutuhkan program-program yang bersifat dadakan (crash program) Sedangkan pengentasan kemiskinan relatif memerlukan kebijaksanaan, strategi, dan program-program yang konsisten untuk jangka panjang, karena berkaitan dengan mengubah dan memelihara pemerataan distribusi pendapatan.

\section{Masyarakat Pedesaan}

Masyarakat pedesaan seringkali dianggap sebagai masyarakat petani atau masyarakat yang mata pencahariannya kebanyakan bertani. Masyarakat pedesaan terdiri dari dua gabungan kata yaitu masyarakat dan pedesaan. Masyarakat adalah segolongan orang yang hidup bersama di tempat atau wilayah yang memiliki ikatan aturan tertentu atau sekumpulan orang-orang yang memiliki kesamaan tertentu. Sedangkan pedesaan dipersepsikan sebagai wilayah pemukiman yang dihuni oleh orang -orang yang berprofesi sebagai petani atau peternak.

Menurut (Shahab, 2013, hal. 65) ciri - ciri masyarakat pedesaan adalah sebagai berikut :(1) Di dalam masyarakat pedesaan memiliki hubungan yang lebih mendalam dan erat bila dibandingkan dengan masyarakat pedesaan lainnya di luar batas-batas wilayahnya. (2) Sistem kehidupan umumnya berkelompok dengan dasar kekeluargaan (paguyuban). (3) Sebagian besar warga masyarakat hidup dari pertanian. Pekerjaan-pekerjaan yang bukan pertanian merupakan pekerjaan sambilan yang biasa mengisi waktu luang.(4) Masyarakat tersebut homogen, seperti dalam hal mata pencaharian, agama, adat istiadat dan sebagainya.

Sedangkan menurut (Beratha, 1982, hal. 43) Unsur-unsur dari pedesaan yang merupakan satu kesatuan dan tidak berdiri sendiri yaitu : (1) Daerah, Adalah tanah-tanah yang 
produktif maupun tidak, beserta penggunaannya. (2) Penduduk, Adalah hal yang meliputi jumlah pertambahan, kepadatan, persebaran dan mata pencaharian penduduk desa setempat. (3) Tata Kehidupan, Dalam hal ini pola pergaulan dan ikatan-ikatan pergaulan warga desa.

Adapun fungsi dari pedesaan yaitu :(1) Dalam hubungannya dengan kota, maka desa merupakan daerah dukung yang berfungsi sebagai suatu daerah pemberian bahan makanan pokok. (2) Desa ditinjau dari sudut potensi ekonomi berfungsi sebagai lumbung bahan mentah dan tenaga kerja. (3) Dari Segi kegiatan kerja, desa dapat merupakan desa agraris, desa manufaktur, desa industri, desa nelayan, dan sebagainya.

\section{METODE PENELITIAN}

Metode yang digunakan dalam penelitian ini adalah metode deskriptif kualitatif. Tujuan dari penelitian deskriptif ini adalah untuk membuat deskripsi, gambaran atau lukisan secara sistematis, faktual dan akurat mengenai fakta-fakta, sifat-sifat serta hubungan antara fenomena yang diselidiki (Nazir, 2009, hal. 54).

Variabel penelitian menggunakan variabel bebas yaitu peran pengelola agrowisata dalam mengentaskan kemiskinan masyarakat pedesaan hal ini sejalan dengan pendapat dari (Sugiyono, Metode Penelitian Pendidikan (Pendekatan Kuantitatif, kualitatif dan R\&D, 2009, hal. 39) yaitu variabel yang mempengaruhi atau yang menjadi sebab perubahan atau timbulnya variabel terikat.

Teknik pengumpulan data pada penelitian ini dilaksanakan di Kawasan Agrowisata Desa Cihideung Kecamatan Parongpong Kabupaten Bandung Barat dengan melakukan wawancara mendalam dan studi lapangan berupa pembagian angket atau kuesioner dengan mengajukan sejumlah daftar pertanyaan yang harus diisi oleh responden yang terdiri dari : 2 orang pengelola yang berasal dari unsur pemerintahan yaitu aparat desa Cihideung , 40 orang masyarakat sekitar kawasan desa Cihideung ini khususnya petani bunga tersebut sebagai objek penelitian dan 10 orang wisatawan/pengunjung yang datang. Dipilihnya aparat desa Cihideung dan petani bunga ini sebagai responden adalah untuk mengetahui sejauh mana kebenaran data yang diberikan oleh pengelola dibandingkan dengan kenyataan yang dirasakan oleh para petani bunga sebagai bahan untuk mengukur seberapa peran pengelola agrowisata di Desa Cihideung ini dalam meningkatkan ekonomi sebagai upaya dalam pengentasan kemiskinan, sedangkan wisatawan/pengunjung adalah untuk menggambarkan testimoni atau hasil dari peran yang telah dilakukan oleh pengelola terhadap petani bunga tersebut. Observasi partisipatif dilakukan langsung ke Agrowisata Desa Cihideung untuk melihat lokasi dan pengambilan dokumentasi. Menurut Model Miles dan Huberman dalam (Sugiyono, Metode Penelitian Kuantitatif, kualitatif dan R\&D, 2012), analisis data di lapangan dilakukan pada saat penelitian berlangsung dan setelah penelitian dilaksanakan, dan dilakukan antisipasi data serta kemudian dilakukan reduksi data untuk menyajikan dalam pola dan verifikasi data. Penelitian ini menggunakan literatur lokal untuk mengakomodasi informasi. Sumbernya berasal dari perpustakaan, buku ilmiah, jurnal, data lembaga pemerintahan terkait dan sumber elektronik sebagai pengayaan informasi terkini. 


\section{HASIL DAN PEMBAHASAN}

Pariwisata dalam hal ini khususnya agrowisata dapat meningkatkan perekonomian suatu negara. Sektor ini memberikan peluang bergeraknya berbagai kegiatan ekonomi masyarakat hal ini sejalan dengan pendapat (Utama, 2017, hal. 15) bahwa pendapatan sektor pariwisata acap kali digunakan untuk mengukur nilai ekonomi pada suatu kawasan wisata..Para wisatawan yang berkunjung pada suatu negara membawa devisa ke negara tersebut. Dengan devisa maka negara akan memperoleh dana pembangunan untuk meningkatkan perekonomian dan memberantas kemiskinan.

Berbagai upaya penggalian maupun pengembangan potensi daerah dituntut untuk meningkatkan sumber penerimaan daerah, sebagai salah satu modal pembiayaan dan penyelenggaraan pembangunan. Pengembangan wisata alam atau agrowisata mampu memberikan kontribusi pada pendapatan asli daerah, membuka peluang usaha dan kesempatan kerja sekaligus berfungsi menjaga dan melestarikan kekayaan alam dan hayati. Sebagai negara agraris yang memiliki kekayaan sumber daya alam berlimpah, pengembangan industri agrowisata seharusnya memegang peranan penting di masa yang akan datang. Melalui perencanaan dan pengembangan yang tepat, agrowisata dapat menjadi salah satu sektor penting dalam ekonomi daerah.

Dalam (Binarwan, Desember 2015, hal. 3) jenis-jenis klasifikasi agrowisata dapat dibagi menjadi 6 (enam), yaitu :

(1) Agrowisata Perkebunan

Kelompok wisata dalam jenis ini dapat dilakukan dalam bentuk kegiatan pra produksi (pembibitan), pemeliharaan dan pasca produksi (pengelolaan dan pemasaran). Salah satu contoh kawasan agrowisata jenis ini di Indonesia adalah Kusuma Agrowisata Batu, Jawa Timur.

\section{(2) Agrowisata Hortikultura}

Kegiatan wisata ini adalah suatu kegiatan wisata di daerah pertanian tanaman hortikultura dan tanaman hias yang dapat juga berupa paket kunjungan ke kebun buah-buahan dan kebun bunga. Para wisatawan dapat menikmati buah-buahan dengan cara memetik sendiri, dan juga dapat melihat secara langsung berbagai teknologi pengolahan yang ada.

(3) Agrowisata Tanaman Pangan

Pertanian tanaman pangan terdiri dari pertanian pangan di lahan basah dan di lahan kering. Komoditas yang dihasilkan di lahan basah adalah padi, sedangkan di lahan kering dataran rendah komoditasnya adalah jagung, kedelai, kacang tanah, serta di dataran tinggi biasanya komoditas yang dihasilkan adalah sayuran.

(4) Agrowisata Perikanan

Agrowisata perikanan merujuk pada penyediaan sarana wisata dan rekreasi bagi wisatawan mulai dari penangkapan komoditas perikanan hingga penyajiannya untuk siap disantap.

(5) Agrowisata Peternakan 
Wisata jenis ini merupakan kegiatan usaha yang bertujuan untuk memepelajari cara-cara beternak tradisional maupun secara modern. Sebagai contoh wisata ternak yang terdaoat di kaki Gunung Tangkuban Perahu bernama "little farmer" yang menyuguhkan wisata hewan-hewan ruminansia seperti sapi, kelinci, hamster dan sebagainya.

\section{(6) Agrowisata Perhutanan}

Agrowisata jenis ini umumnya terkait dengan hutan produksi ataupun hasil tanaman hutan seperti mahono, jati, pinus, rasamala, rimba dan damar.Daya tarik agrowisata ini antara lain melihat dan berburu binatang, petik jamur dan berry, orientasi alam, maupun studi alam.

Menurut Peraturan Daerah Kabupaten Bandung Barat Nomor 4 Tahun 2012 tentang Rencana Induk Pengembangan Pariwisata Kabupaten Bandung Barat bahwa terdapat kawasan yang ditetapkan sebagai wisata agro di Kabupaten Bandung Barat yaitu Kecamatan Parongpong salah satunya. Kawasan tersebut dipilih menjadi kawasan wisata agro disamping karena memiliki potensi pertanian yang melimpah , juga karena kawasan ini berada pada kawasan Agropolitan Kabupaten Bandung Barat yaitu Agropolitan Lembang.

Perencanaan dan pengembangan kawasan agrowisata ini tidak lepas dari peran berbagai pihak yang terkait yaitu pengelola, petani maupun wisatawan itu sendiri. Peran mereka bersama dengan interaksi mereka adalah penting untuk menuju sukses pengembangan agrowisata ini. Sampai saat ini berbagai objek wisata yang potensial relatif belum banyak menarik pengunjung, antara lain karena terbatasnya sarana dan prasarana yang tersedia dan kurangnya promosi dan pemasaran kepada masyarakat luas baik di dalam maupun di luar negeri. Untuk itu perlu ditempuh suatu koordinasi promosi antara pengelola dengan berbagai pihak yang berkecimpung dalam bidang promosi dan pemasaran objek-objek agrowisata, baik instansi pemerintah maupun pihak swasta.

Menurut Keputusan Presiden RI No. 29 Tahun 2003 pasal 20 yaitu intinya bahwa penyelenggaraan pariwisata berkelanjutan ada empat karakteristik peran dari stakeholder yaitu:

(1) Pemerintah pusat sebagai fasilitator/regulator.

Antara lain yaitu perumusan kebijakan pemerintah di bidang kebudayaan dan pariwisata; pengkoordinasian dan peningkatan keterpaduan penyusunan rencana dan program, pemantauan, analisis dan evaluasi di bidang kebudayaan dan pariwisata; peningkatan peran serta masyarakat dan dunia usaha kebudayaan dan pariwisata dalam memajukan kebudayaan dan pariwisata; serta menyampaikan laporan hasil evaluasi, saran dan pertimbangan di bidang tugas dan fungsinya kepada presiden. Dalam hal pembangunan infrastruktur, pemerintah dapat bermitra dengan pihak swasta. Pemerintah pusat juga berperan dalam pengembangan kapasitas sumber daya manusia, baik staf birokrasi maupun masyarakat. Pengembangan sumber daya manusia dalam konteks pariwisata berkelanjutan bukan ditujukan untuk kepentingan lokal, melainkan untuk standar nasional sehingga memenuhi standar pelayanan pariwisata global.

(2) Pemerintah daerah sebagai sebagai dinamisator. 
Pemerintah sebagai salah satu komponen substansi penyelenggaraan kepariwisataan mempunyai peran yang sangat luas. Dalam era otonomi ini, daerah berperan sebagai dinamisator/pendorong pengembangan pariwisata. Pemerintah propinsi dan kabupaten/kota dapat berinisiatif merencanakan bahkan dapat berperan dalam seluruh proses penyelenggaraan sebagai katalisator. Pemerintah daerah sebagai dinamisator pembangunan di wilayahnya berperan dalam perencanaan pembangunan serta implementasi regulasi sampai tahap evaluasi dan pemantauan kegiatan pariwisata.

(3) Swasta dan masyarakat sebagai operator.

Dalam pariwisata berkelanjutan, swasta dan masyarakat memang diharapkan mengambil inisiatif dan melakukan investasi yang lebih besar berkelanjutan tidak berarti investasi tetapi pengelolaan yang ramah lingkungan dalam pembangunan kepriwisataan di Indonesia. Swasta berperan terutama untuk pengembangan komponen aksesibilitas (kemudahan akses) dan amenitas (fasilitas/sarana pariwisata). Swasta dalam perannya dapat bermitra dengan masyarakat dalam mempersiapkan akomodasi dan atraksi. Khusus untuk atraksi, masyarakat diharapkan menjadi operator utama. Masyaeakat dalam wisata alam misalnya, dapat menjadi petunjuk jalan, dan dalam pementasan unsur-unsur budaya dapat menyelenggarakan menurut aturan dan adat istiadatnya.

(4) Pemerintah,swasta dan masyarakat sebagai pengguna jasa.

Jasa dari pariwisata ini pada akhirnya dapat dirasakan dan dinikmati oleh semua unsur baik pemerintah, swasta dan masyarakat yang dalam hal ini berperan sebagai pengguna jasa.

Dalam penyelenggaraan pariwisata, ketiga peran (fasilitator, dinamisator dan operator) sangat menentukan tingkat keberhasilan pengelolaan komponen daya tarik wisata (sumber daya alam termasuk pengelolaan agrowisata dan budaya) karena peran merupakan aspek dinamis dari kedudukan apabila seseorang melakukan hak dan kewajibannya sesuai dengan kedudukannya, berarti dia telah menjalankan suatu peran (Suwantoro, 2004, hal. 34).

Beberapa keuntungan ekonomi dari potensi agrowisata yaitu antara lain :

(1) Peningkatan pendapatan masyarakat yang dihasilkan melalui berbagai kegiatan penjualan dari hasil cocok tanam, seperti sayur-sayuran, buah-buahan, bunga, palawija, ikan, susu dapat dijual langsung kepada pengunjung maupun hasil yang dijual untuk memenuhi kebutuhan masyarakat pada umumnya. Upaya ini merupakan pendapatan langsung yang dihasilkan dari pembelian wisatawan di lokasi agrowisata memberikan dampak yang cukup luas terhadap kelangsungan dan keberadaan agrowisata.

(2) Berbagai macam kegiatan bisa dilakukan di objek wisata agrowisata ini sehingga menambah alternatif wisata yang baru.

(3) Membuka kesempatan berusaha. Keanekaragaman jenis agrowisata mengembangkan lahan yang diperuntukkan bagi kegiatan bercocok tanam masyarakat. Berbagai jenis komoditi bagi wisatawan disediakan oleh masyarakat pada lahan yang dimiliki latar belakang keindahan, kesejukan, kenyamanan sehingga para pengunjung dapat melakukan rekreasi di lokasi yang dipersiapkan untuk agrowisata. Dengan berkembangnya jumlah 
wisatawan/ pengunjung ke lokasi agrowisata akan memberikan pengaruh efek ganda dalam mengembangkan usaha masyarakat seperti hasil komoditi pertanian dan lain-lain.

(4) Agrowisata yang dihasilkan oleh peningkatan kunjungan wisatawan, lama tinggal wisatawan dan belanja wisatawan untuk meningkatkan pendapatan para petani.

(5) Daya dukung promosi. Negara menjadi terkenal oleh karena hasil dari komoditi pertanian yang menyebar luas ke berbagai Negara dan di konsumsi oleh masyarakat. Indonesia sebagai Negara agraris telah banyak memperkenalkan melalui berbagai komoditi pertanian, peternakan, perikanan dan lain-lain. Dengan brkembangnya agrowisata di suatu daerah, akan mendorong menjadi terkenal dan menjadi perhatian wisatawan untuk berkunjung ke negara tersebut. Dampak yang cukup menarik adalah adanya keterkaitan antara agrowisata dengan promosi paariwisata.

(6) Meningkatkan produksi dan kualitas. Peningkatan hasil produksi pertanian merupakan acuan dasar bagi tumbuh kembangnya sektor pertanian. Pengelolaan agrowisata dengan baik dapat berpengaruh terhadap peningkatan produksi masing-masing komoditas yang diusahakan. Kualitas dari komoditas yang dihasilkan oleh pengelola agrowisata, selektif dan menjadi perhatian pengelola. Segala sesuatu yang disajikan memiliki kualitas, mengingat para wisatawan yang membeli hasil pertanian dapat mengkonsumsi dan membeli langsung dari masyarakat untuk dinikmati.

Agrowisata yang dibina secara baik berdasarkan kemampuan masyarakat, dapat memberikan dampak bagi peningkatan ekonomi masyarakat dalam bentuk menambah pendapatan masyarakat, kesempatan kerja, dan kesempatan berusaha sehingga secara tidak langsung itu adalah merupakan upaya dalam pengentasan kemiskinan pada masyarakat di pedesaan. Hal ini diperkuat oleh pendapat dari (Tjokrowinoto, 2005, hal. 5) bahwa pariwisata dapat mengurangi tingkat kemiskinan karena karakteristiknya yang khas sebagai berikut : (1) Konsumen datang ke tempat tujuan sehingga membuka peluang bagi penduduk lokal untuk memasarkan berbagai komoditi dan pelayanan, (2) Membuka peluang bagi upaya untuk mendiversifikasikan ekonomi lokal yang dapat menyentuh kawasan-kawasan marginal, (3) Membuka peluang bagi upaya usaha-usaha ekonomi padat karya yang berskala kecil dan menengah yang terjangkau oleh kaum miskin, dan (4) Tidak hanya tergantung pada modal budaya ( cultural capital) yang seringkali merupakan aset yang dimiliki oleh kaum miskin.

Agrowisata tidak terbatas pada objek dengan agrowisata yang luas, agrowisata bisa dilakukan dengan skala yang kecil dan diharapkan dapat menjadi media pendidikan dan budaya, daya tarik wisata ini menjadi sarana promosi produk lokal.

Pendekatan pengembangan agrowisata, meliputi: (1) Pengembangan berbasis konservasi, dimaksudkan pola pembinaan yang tetap mempertahankan keasrian agro-ekosistem dengan mengupayakan kelestarian sumber daya alam lingkungan hidup, sejarah, budaya dan rekreasi. (2) Pengembangan berbasis masyarakat, dimaksudkan pola pembinaan masyarakat yang menempatkan agrowisata sebagai pemberdayaan masyarakat petani untuk dapat memperoleh nilai tambah baik dari sisi hasil pertanian dan kunjungan wisata serta efek ganda dari penyerapan hasil pertanian yang merupakan sinergiats antara industri pariwisata/pengelola pariwisata dan masyarakat serta pemerintah. (3) Penetapan 
wilayah sebagai daerah agrowisata/wilayah pembinaan. (4) Inventarisasi kekuatan agrowisata. (5) Peranan lembaga pariwisata dan lembaga pertanian dalam pembinaan agrowisata. (6) Pembinaan agrowisata oleh pemerintah.

Pada umumnya pertanian bunga hias atau agrowisata di Desa Cihideung ini telah memberikan simpati bagi Pemerintah Kabupaten Bandung Barat dan membantu dalam upaya pengentasan kemiskinan masyarakat pedesaan dengan cara meningkatkan perekonomian daerah sekitar Desa Cihideung. Dan Selanjutnya agrowisata di Desa Cihideung ini mengalami perkembangan yang sangat pesat sehingga Pemerintah Kabupaten Bandung Barat ikut berpartisipasi dalam membantu perkembangannya melalui kelompok-kelompok tani, dan salah satu kelompok tani yang sudah dibentuk oleh masyarakat di Desa Cihideung ini adalah kelompok Tani Giri Mekar. Jenis partisipasinya yaitu berupa aspek permodalan, pelatihan, sumber daya manusia serta berbagai penyuluhan dalam cara-cara penanaman bunga diikuti dengan penyuluhan macam-macam obat-obatan pestisida yang cocok untuk tanaman bunga.

Konsep yang dijalankan oleh pengelola melalui program agrowisata yang lebih modern untuk mendorong berkembangnya sistem dan usaha pertanian dalam suatu sistem yang menyeluruh, berdaya saing, berbasis kerakyatan, berkelanjutan dan terdesentralisasi yang digerakkan oleh masyarakat dan difasilitasi oleh Pemerintah. Peran aktif pemerintah ini merupakan upaya yang positif dalam meningkatkan kesejahteraan masyarakat pedesaan, khususnya petani bunga hias di Desa Cihideung.

\section{KESIMPULAN}

Kesimpulannya adalah sebagai berikut: Pertama, Agrowisata ini sangat cocok diterapkan di Desa Cihideung mengingat kondisi alamnya dengan hawa yang sejuk dan udara yang masih sangat segar membuat pengunjung atau wisatawan baik yang hanya sekedar berjalan-jalan saja ataupun yang membeli hasil agrowisata ini akan merasa nyaman dan bisa menghilangkan stress akibat beban dan rutinitas pekerjaan dan karena keunikan dan daya tarik dari daerah agrowisata ini, maka kini kawasan Desa Cihideung ini menjadi pusat tanaman terlengkap di Bandung. Kedua, Agrowisata yang dibina secara baik berdasarkan kemampuan masyarakat, dapat memberikan dampak bagi peningkatan ekonomi masyarakat dalam bentuk menambah pendapatan masyarakat, kesempatan kerja, dan kesempatan berusaha sehingga secara tidak langsung itu adalah merupakan upaya dalam pengentasan kemiskinan pada masyarakat di pedesaan. Ketiga, Perencanaan dan pengembangan kawasan agrowisata ini tidak lepas dari peran berbagai pihak yang terkait yaitu pengelola, petani maupun wisatawan itu sendiri. Peran mereka bersama dengan interaksi mereka adalah penting untuk menuju sukses pengembangan agrowisata ini. Sampai saat ini berbagai objek wisata yang potensial relatif belum banyak menarik pengunjung, antara lain karena terbatasnya sarana dan prasarana yang tersedia dan kurangnya promosi dan pemasaran kepada masyarakat luas baik di dalam maupun di luar negeri. Untuk itu perlu ditempuh suatu koordinasi promosi antara pengelola dengan berbagai pihak yang berkecimpung dalam bidang promosi dan pemasaran objek-objek agrowisata, baik instansi pemerintah maupun pihak swasta.

Ada empat karakteristik peran dari stakeholder yaitu: (1) pemerintah pusat sebagai fasilitator, (2) pemerintah daerah sebagai sebagai dinamisator, (3) swasta dan masyarakat 
sebagai operator, (4) pemerintah,swasta dan masyarakat sebagai pengguna jasa. Keempat peran ini yang dapat saling mendukung menurut fungsi, skala, pengendalian, sifat kelembagaan, bentuk kelembagaan dan spesifikasinya

\section{DAFTAR PUSTAKA}

Awan Setya Dewanta, d. (1995). Kemiskinan dan Kesenjangan di Indonesia. Yogyakarta: Aditya Media.

Beratha, N. (1982). Masyarakat Desa dan Pembangunan Desa. Jakarta: Ghalia Indonesia.

Binarwan, R. (Desember 2015). Taman Bunga Cihideung Bandung Barat Merupakan Tempat Agrowisata Berbasis Masyarakat. Jurnal Kepariwisataan Indonesia Volume 10 No.1 , ISSN 1907-9419.

Nazir, M. (2009). Metode Penelitian. Jakarta: Cetakan Pertama Penerbit Ghalia Indonesia.

Shahab, K. (2013). Sosiologi Pedesaan. Yogyakarta: Ar-Ruzz Media.

Soekanto, S. (1995). Sosiologi Suatu Pengantar. Jakarta: PT. Raja Grafindo Persada.

Sugiyono. (2009). Metode Penelitian Pendidikan (Pendekatan Kuantitatif, kualitatif dan $R \& D$. Bandung: Cetakan ke 8 Penerbit CV. Alfabeta.

Sugiyono. (2012). Metode Penelitian Kuantitatif, kualitatif dan R\&D. Bandung: Alfabeta.

Suwantoro, G. (2004). Dasar-dasar Pariwisata. Yogyakarta: Andi.

Tjokrowinoto, M. (2005). Pengurangan Kemiskinan Melalui Pariwisata. Perspektif Kebijakan Publik. Dalam Damanik, J., H.A. dan Raharjana, D.T (Ed).

Utama, I. G. (2017). Pemasaran Pariwisata. Yogyakarta: Penerbit Andi.

Yoeti, O. A. (2000). Ekowisata Pariwisata Pariwisata Berwawasan Lingkungan Hidup. Jakarta: Perca Indonesia. 